\title{
Monitoring mangrove forests after aquaculture abandonment using time series of very high spatial resolution satellite images: A case study from the Perancak estuary, Bali, Indonesia
}

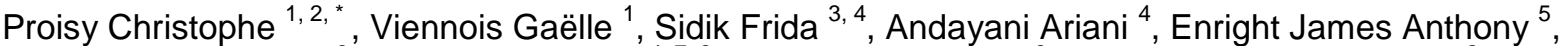 \\ Guitet Stéphane ${ }^{6}$, Gusmawati Niken ${ }^{4,7,8}$, Lemonnier Hugues ${ }^{8}$, Muthusankar Gowrappan ${ }^{2}$, \\ Olagoke Adewole ${ }^{1,9}$, Prosperi Juliana ${ }^{1}$, Rahmania Rinny ${ }^{1,4}$, Ricout Anaïs ${ }^{2}$, Soulard Benoit ${ }^{8}$, \\ Suhardjono ${ }^{10}$
}

\footnotetext{
${ }_{1}^{1}$ AMAP, IRD, CNRS, CIRAD, INRA, Université de Montpellier, Montpellier, France

${ }^{2}$ Geomatics and Applied Informatics Laboratory (LIAG), French Institute of Pondicherry, Pondicherry, India

${ }^{3}$ The Institute for Marine Research and Observation, The Agency for Marine and Fisheries Research, The Ministry of Marine Affairs and Fisheries, Perancak, Bali, Indonesia

${ }^{4}$ The Agency for Marine and Fisheries Research, Ministry of Marine Affairs and Fisheries, Jakarta, Indonesia

${ }^{5}$ Mangrove Action Project, Trang, Thailand

${ }_{7}^{6}$ GIP ECOFOR, Paris, France

${ }^{7}$ University of New Caledonia, Nouméa, New Caledonia

${ }^{8}$ IFREMER, LEAD/NC, Nouméa, New Caledonia

${ }^{9}$ Institute of Forest Growth and Computer Science, Technische Universität, Dresden, Germany

${ }^{10}$ Herbarium Bogoriense, Indonesian Institute of Sciences (LIPI), Bogor, Indonesia

*Corresponding author : Christophe Proisy, email address : christophe.proisy@ird.fr
}

\begin{abstract}
:
Revegetation of abandoned aquaculture regions should be a priority for any integrated coastal zone management (ICZM). This paper examines the potential of a matchless time series of 20 very high spatial resolution (VHSR) optical satellite images acquired for mapping trends in the evolution of mangrove forests from 2001 to 2015 in an estuary fragmented into aquaculture ponds. Evolution of mangrove extent was quantified through robust multitemporal analysis based on supervised image classification. Results indicated that mangroves are expanding inside and outside ponds and over pond dykes. However, the yearly expansion rate of vegetation cover greatly varied between replanted ponds. Ground truthing showed that only Rhizophora species had been planted, whereas natural mangroves consist of Avicennia and Sonneratia species. In addition, the dense Rhizophora plantations present very low regeneration capabilities compared with natural mangroves. Time series of VHSR images provide comprehensive and intuitive level of information for the support of ICZM.
\end{abstract}




\section{Highlights}

- Very high spatial resolution satellite (VHSR) images were used. Revegetation was mapped over pond floors, pond walls, and unimpeded areas. Monocultural plantations were mapped even at the earliest stages. Their growth and expansion are not assured in every disused pond. $>$ Stakeholders can undertake ICZM under sentinel watch by VHSR satellite sensors.

Keywords : Mangroves, Rehabilitation, Rhizophora plantations, Shrimp ponds, Remote sensing, ICZM 


\section{Introduction}

The ever-growing appetite of the aquaculture industry for new land areas takes a heavy toll on mangrove ecosystems (Alongi 2002; Giri et al. 2015; Richards and Friess 2016; Valiela et al. 2001), to the extent that their future is not guaranteed (Duke et al. 2007; Friess et al. 2016). Stevenson et al. (1999) warned that "even if the shrimp industry were to achieve sustainability today, disused shrimp ponds would still remain, as would the poverty and the environmental problems they create". Revegetation of disused ponds, over thousands of square kilometers, may partially offset mangrove losses resulting from the unsustainable legacy of aquaculture practices. This should be a priority of any ongoing integrated coastal zone management (ICZM) plan (Bosma et al. 2012; Carter et al. 2015).

In Indonesia, in the period between 1980 and 2003, characterized by weak governance of the aquaculture sector (IIman et al. 2016), thousands of hectares of coastal zone were transformed into a mosaic of aquaculture ponds, of which about 250,000 ha have remained disused ever since (Gusmawati et al. this issue). The scale of the conversion is particularly visible in large areas like the Mahakam delta covering about $75,000 \mathrm{~km}^{2}$ in East Kalimantan, Borneo Island (Dutrieux et al. 2014). Anyone using Google Earth, with its high-resolution satellite images, can see and understand the scale of the impact of aquaculture on such coastal areas. In Indonesia alone, a further 600,000 hectares of mangrove are projected for conversion into aquaculture ponds in the next 20 years (Ilman et al. 2016) because the lifespan of intensive shrimp farming does not exceed 10 years (Boyd and Clay 1998; Sathirathai 1998). It is therefore quite frightening to consider the further enormous waste that will result. We know that mangroves provide a diversity of ecosystem services (Barbier et al. 2011) that are estimated to total about US $\$ 194,000$ ha/year (Costanza et al. 2014) and their value is further increasing due to recognized roles in, for example, coastal protection (Barbier 2016) and wastewater management (Bouchez et al. (2013). It is apparent that the cost-benefit equation of aquaculture development is biased and uncalibrated. 
In areas converted by aquaculture, monitoring programs are necessary to document mangrove coast degradation (Ilman et al. 2016) as a prerequisite for any mangrove rehabilitation plan (Lewis 2005) and toward restoration of good environmental conditions. The viability of existing replanting programs and evaluation of the potential for natural recolonization also require monitoring (Check 2005; Primavera et al. 2016; Primavera and Esteban 2008). Mangrove replanting programs need detailed justification (Duncan et al. 2016; Lewis 2005, 2009; Samson and Rollon 2008) and the "revival" of each disused pond should be carefully and individually implemented based on the testing of different mangrove management regimes for different ecosystem services (van Oudenhoven et al. 2015b). Different silvo-fishery models, all including mangroves on pond floors and/or pond walls, could be experimented with in the context of the local environment and then monitored (van Oudenhoven et al. 2015a).

Lewis et al. (2016) note that observational programs have to be established by "embedding plot and remote sensing monitoring." However, the extent, spatial complexity, and temporal variability of areas fragmented by brackish-water aquaculture (Fig. 1) cannot be fully explored by ground observation even when combined with remote sensing images of medium spatial resolution (MSR), i.e., with a pixel size greater than $5 \mathrm{~m}$. Mapping of large-scale conversion of mangroves can be roughly approximated using methods based on MSR images (Rahman et al. 2013). Identification and accurate delineation of aquaculture ponds and mangrove areas cannot be achieved using MSR images, as illustrated in Fig. 1.

Spatial observations at fine scale delivered by aerial photographs or very high spatial resolution (VHSR) satellite images provide more interpretable information on ecosystems (Benfield et al. 2005; Kuenzer et al. 2011; Oliver et al. 2012; Rapinel et al. 2014). Such satellite imagery, with pixel sizes ranging from $30 \mathrm{~cm}$ to $4 \mathrm{~m}$, is increasingly available at affordable prices since the launch of the Ikonos satellite in 2001. Pixel intensities are the result of light scattering mechanisms within areas of a few square meters and provide an intuitive perception of the forest structure organization (Proisy et al. 2007) and canopy gaps (Amir 2012). Tree 
crowns can be identified and planting density estimated at early developmental stages as demonstrated by Zhou et al. (2013) for Eucalyptus plantations.

This study examines the combined potential of ground truth and a unique time series of VHSR satellite images in the development of a monitoring system that could improve mangrove management after aquaculture abandonment in Bali, Indonesia. We started the analysis of the Perancak estuary, Bali, Indonesia with little background knowledge on the present status of the estuarine processes and management, apart from studies of Sidik and Lovelock (2013) on $\mathrm{CO}_{2}$ emission from shrimp ponds, Lovelock et al. (2015) on vulnerability of mangrove forests to sea level rise, and (Gusmawati et al. this issue) on the monitoring of aquaculture pond activity. The study aims to assess mangrove status and evolutionary trends in terms of extent, type (planted vs. natural), forest structure, and species composition in an estuary extensively fragmented by conversion to aquaculture ponds. Visual expertise and supervised classification methods were employed in parallel to provide meaningful information for monitoring mangrove changes. A situation diagnosis for the study site is followed by discussion of the overall potential of temporal series of VHSR imagery for improving ICZM plans on mangrove coasts.

\section{Material and methods}

\subsection{Site description}

The study area is the Perancak estuary, located in west Bali ( $\left.8^{\circ} 23^{\prime} \mathrm{S}, 114^{\circ} 37^{\prime} \mathrm{E}\right)$, Indonesia, which extends over $7.55 \mathrm{~km}^{2}$ (Fig. 2). The average annual air temperature is $26.6^{\circ} \mathrm{C}$ with the dry season lasting from May to September. Additional information on the Perancak estuary climatic environment is given in (Gusmawati et al. this issue). The Perancak estuary receives runoff from two mountain catchments. To our knowledge, there is no station recording variations in the river flow levels and currents. Low tide reveals a water depth of a few meters at the river mouth and shallow waters upstream. There is no tidal gauge station in the estuary; 
the closest one is located $6 \mathrm{~km}$ west on the seashore, near the fishing harbor of Pengambengan. As the bathymetry of Perancak tributary rivers is not known, tidal variations cannot be derived accurately in the Perancak estuary, even less over pond floors surrounded by dykes.

The history of conversion of the Perancak estuary over recent decades is probably typical of many Indonesian mangrove coasts subject to aquaculture development (Ilman et al. 2016). In 1965, ponds were already in place as observed in a Corona declassified image produced by the U.S. Geological Survey (not shown). They surrounded the central river catchment region and covered only about $30 \%$ of the whole estuary. By the late 1970 s, about $4.4 \mathrm{~km}^{2}$ of the mangrove area, effectively the whole available area, had been converted to fish or shrimp aquaculture ponds (Ministry of Marine Affairs and Fisheries, personal communication). The industry flourished during the 1980s but productivity declined in the 1990s. Only a few farms remain active in the upstream and downstream parts of the Perancak estuary (Gusmawati et al. this issue). We observed that the state of pond wall can greatly vary over the estuary. Some of these walls are noticeably maintained, others are eroded. Moreover, wall openings are of different widths and depths; some other ponds are connected to the river through underground piping.

Plantation programs might have been then initiated by, in particular, the Japan International Cooperation Agency, which introduced mangroves in the disused ponds. Private and public landowners have continued planting mangrove seedlings since 2000. The motivations and planting specifications have not been clearly identified. We could not determine why several small private owners planted mangroves, but an adjacent plantation program of over 12.3 ha, carried out after 2007 by a private company affiliated to the Denpasar International Airport, was said to have been conducted as compensation for the airport extension. We are not aware of any harvest (or management) plans for the planted mangroves. However, large pond areas planted with Nypa fruticans palms trees are regularly harvested for building palm frond roofs and not for supporting any mangrove restoration effort. To our 
knowledge, forest structure and extent of mangrove are not yet described and mapped in the Perancak estuary

\subsection{Forest data}

Field experiments were carried out over a total of 20 days in May and November 2014. Forest areas for field sampling were selected after comparative analysis of VHSR images with the aim of capturing the largest possible range of forest characteristics. We paid particular attention to ponds where new seedlings were planted to complete an inventory in plantations of different ages. On the field, mangrove forests were classified as planted systems when it was clear that the trees had been planted in a regular and tightly spaced pattern. By contrast, mangroves in which the distance between trees of different species greatly varied were classified as natural. Both types of mangroves could be found inside and outside ponds but the areas of natural mangroves mainly corresponded to unimpeded zones with hydrological connections to unblocked water flows.

Data were collected within delineated forest areas ranging in size from $100 \mathrm{~m}^{2}$ for young stages with a high density of trees to $2500 \mathrm{~m}^{2}$ for adult natural mangroves (Supplementary Table 1). After species identification, we measured the diameter at breast height (DBH) for all individual trees of $\mathrm{DBH}$ values greater than $1 \mathrm{~cm}$. We also evaluated heights of dominant trees using a laser rangefinder and recorded the number of seedlings of a given species inside the considered plot. The final forest dataset is composed of 16 plots (Supplementary Figure $1 ; 11$ in plantations, 5 in natural forests). The dataset was complemented by $\mathrm{DBH}$ records and species identification in seven additional places with adult mangroves. Finally, numerous observations of the floristic diversity were made in areas where significant numbers of natural and planted seedlings were encountered.

We derived several structural and floristic parameters from the forest data (Supplementary Table 1). They included the mean quadratic diameter Dq for all trees, the number of trees $\mathrm{N}$, the plot basal area $\mathrm{G}$ which is reduced to the sum of individual basal areas for $\mathrm{DBH}$ records datasets. For each plot, we computed the average number of basal shoots 
(NStt) per tree of a given species. We recorded the total number of mangrove tree species (NSP), the dominant species in the plot (DSP), those with a basal area higher than $10 \%$ of $\mathrm{G}$, and regenerative seedling species (DSPR), if accounting for more than $5 \%$ of the total number of seedlings.

\subsection{VHSR satellite images}

Twenty VHSR images acquired from 2001 to 2015 by different satellite sensors were delivered in a GeoTIFF format with pixel size ranging from 0.5 (Geoeye, Quickbird, Worldview2 and Worldview-3) $\mathrm{m}$ to $1 \mathrm{~m}$ (Ikonos) for panchromatic channels and from $2 \mathrm{~m}$ to $4 \mathrm{~m}$ in multispectral channels (Table 1). The registration of all images was refined using the GeoEye image of October 1, 2010 as the reference image for superposition. We estimated the spatial registration accuracy as 1-2 $\mathrm{m}$. The pixel intensity (or digital number) was transformed into top-of-atmosphere (TOA) reflectance value, without correction for atmospheric effects, as follows:

$$
\rho=\frac{\pi \cdot L_{\lambda} \cdot D^{2}}{E_{\operatorname{sun}} \cdot \cos \theta_{s}}
$$

where $\rho$ is the pixel reflectance, $L_{\lambda}$ is the radiance obtained using sensor-specific equations provided in the image metadata files, $D$ is the Sun-Earth distance (expressed in astronomical units), $E_{\text {sun }}$ is the corresponding mean solar exoatmospheric spectral irradiance $\left(\mathrm{mW} \mathrm{cm}{ }^{-2} \mu \mathrm{m}^{-}\right.$ $\left.{ }^{1}\right)$, and $\theta_{s}$ is the solar zenith angle. Image analysis, carried out under ERDAS ER MAPPER 2016 software, was based on multichannel reflectance images composed of multispectral channels resampled to the spatial resolution of the panchromatic channels.

\subsection{Image analysis}

\subsubsection{Geographic Information System-based photointerpretation}

Several Geographic Information System (GIS) layers were created by visual delineation using ArcGIS10. $3^{\circledR}$ software giving the results in Fig. 2. As shown in Fig. 3, visual interpretation 
started by delineating the region of interest (ROI), i.e., the $7.55 \mathrm{~km}^{2}$ estuarine zone subject to tidal influence. This was done by following the border formed by outer banks and vegetation (rice fields, palm forests, etc.), which have contrasting spectral and textural signatures compared with mangrove multispectral responses. We then delineated the surface water system and human infrastructure, while all shrimp ponds were digitized into polygon layers. Ancillary GIS layers such as roads were also digitized as polyline layers. The potential area for mangrove expansion over natural areas was thus derived. In addition, it was possible to discriminate planted mangroves from the natural forests since the row and regular organization of plantations was observable even at the earliest stages (Fig. 4).

\subsubsection{Maximum likelihood supervised image classification}

Mangrove areas were distinguished from other surface types using a pixel-based algorithm for maximum likelihood supervised classification (MLSC) (see Wilkinson (2005) for a review of image classification methods). Ground truth was helpful for the training and interpretation of the classification work. We generated training and validation sets by delineating tens of polygons spatially distributed across the whole estuary. Non-mangrove polygons included water surfaces, pond floors, pond walls, and bare soils. We directly applied the MLSC to each multichannel image and produced a confusion matrix consisting of the user and producer accuracy values for the two classes (mangrove and non-mangrove), an overall accuracy, and a kappa coefficient. For consistency, we only include a table that summarizes the producer and overall accuracy levels and the associated kappa coefficients (Table 1).

\section{Results}

\subsection{Performance of multitemporal "mangrove-non-mangrove" supervised classification}

In all satellite images, mangrove areas were discriminated from non-mangrove areas with overall accuracy and kappa coefficient values ranging from $95 \%$ to $100 \%$ and 0.81 to 0.99 , respectively (Table 1). Even the lowest producer accuracies for the mangrove class, obtained 
from 2001 to 2003 using the lkonos-2 images, were above $90 \%$. Mangrove areas were globally better classified in images acquired after 2007 with producer accuracy and kappa values reaching 0.99 .

Table 1 : Image parameters and metadata of VHSR images acquired over the Perancak estuary. Low, intermediate (noted inter.) and high flooding levels estimated from visual analysis are given in the third column. The angles $\theta_{s}$, $\theta_{v}$, and $\phi_{s-v}$ denote the sun zenith, viewing zenith angle, and the relative sun-viewing azimuth angles, respectively. Producer accuracy for both mangrove and non-mangrove classes with overall accuracy and kappa coefficient are indicated in the four columns on the right.

\begin{tabular}{|c|c|c|c|c|c|c|c|c|c|}
\hline \multirow[b]{2}{*}{ Satellite } & \multirow[b]{2}{*}{$\begin{array}{c}\text { Acquisition } \\
\text { date }\end{array}$} & \multirow[b]{2}{*}{$\begin{array}{c}\text { Flooding } \\
\text { level }\end{array}$} & \multirow[b]{2}{*}{$\begin{array}{l}\theta_{\mathrm{s}} \\
\left({ }^{\circ}\right)\end{array}$} & \multirow[b]{2}{*}{$\begin{array}{l}\theta_{v} \\
\left({ }^{\circ}\right)\end{array}$} & \multirow[b]{2}{*}{$\begin{array}{c}\Phi_{s-\mathrm{v}} \\
\left({ }^{\circ}\right)\end{array}$} & \multicolumn{2}{|c|}{ Producer accuracy } & \multirow[b]{2}{*}{$\begin{array}{l}\text { Overall } \\
\text { accuracy }\end{array}$} & \multirow[b]{2}{*}{ Kappa } \\
\hline & & & & & & Mangrove & $\begin{array}{c}\text { Non- } \\
\text { Mangrove }\end{array}$ & & \\
\hline \multirow{5}{*}{ Ikonos } & 02-Aug-01 & High & 34 & 53 & 178 & 95,40 & 99,70 & 99,10 & 0,96 \\
\hline & $12-$ Oct-01 & Low & 20 & 15 & 95 & 100,00 & 95,20 & 95,70 & 0,81 \\
\hline & 09-Mar-02 & Inter. & 28 & 23 & 16 & 96,00 & 99,90 & 99,50 & 0,97 \\
\hline & 21-Feb-03 & High & 24 & 15 & 129 & 90,80 & 99,90 & 99,40 & 0,94 \\
\hline & 27-Jun-03 & High & 39 & 15 & 62 & 99,00 & 99,90 & 99,90 & 0,90 \\
\hline \multirow{3}{*}{ QuikcBird } & 22-Sep-07 & Low & 19 & 19 & 112 & 98,15 & 100,00 & 99,60 & 0,99 \\
\hline & 19-Jul-08 & High & 36 & 11 & 148 & 89,90 & 99,90 & 98,30 & 0,94 \\
\hline & 09-Jul-09 & Low & 38 & 18 & 176 & 99,70 & 99,90 & 99,90 & 0,90 \\
\hline WorldView-2 & 16-Aug-10 & Inter. & 38 & 18 & 2 & 98,80 & 99,90 & 99,70 & 0,99 \\
\hline \multirow{3}{*}{ GeoEye } & 01-Oct-10 & Low & 24 & 25 & 67 & 99,90 & 98,50 & 99,50 & 0,99 \\
\hline & $18-$ Oct-10 & High & 18 & 28 & 157 & 99,50 & 99,50 & 99,50 & 0,99 \\
\hline & 23-Oct-10 & High & 22 & 25 & 58 & 98,60 & 99,70 & 99,50 & 0,99 \\
\hline \multirow{6}{*}{ WorldView 2} & 15-Apr-11 & High & 29 & 26 & 81 & 99,90 & 98,70 & 98,90 & 0,97 \\
\hline & 30-Jun-11 & High & 36 & 16 & 104 & 99,90 & 99,50 & 99,60 & 0,98 \\
\hline & 23-Oct-12 & Low & 13 & 20 & 144 & 99,90 & 99,90 & 99,90 & 0,99 \\
\hline & 01-May-13 & High & 28 & 13 & 132 & 99,30 & 98,70 & 98,90 & 0,96 \\
\hline & 10-Dec-13 & Inter. & 23 & 10 & 16 & 97,90 & 96,26 & 97,00 & 0,93 \\
\hline & 26-Mar-14 & Inter. & 25 & 17 & 86 & 99,30 & 99,90 & 99,70 & 0,99 \\
\hline GeoEye & 11-Oct-14 & High & 20 & 19 & 52 & 99,90 & 99,90 & 99,90 & 0,99 \\
\hline WorldView-3 & 16-Apr-15 & High & 31 & 10 & 26 & 99,50 & 100,00 & 99,90 & 0,99 \\
\hline
\end{tabular}

Additional performance assessment could be derived from multitemporal analysis. Significant differences between the numbers of "mangrove" pixels classified for two close dates could mean either a real mangrove loss or a lack of robustness in the classification method. The advantage of using VHSR images is that apparent mangrove loss is easily checked (confirmed or refuted) by visual comparison of a pair of classified images. As shown in Fig. 5 (top), the total mangrove extent decreased from 60 ha to 40 ha from 2001 to 2003. We attributed this decrease to cutting of natural mangroves along riverbanks and over pond walls 
in the western part of the estuary. After 2007, the number of pixels classified as "mangrove" increased quite regularly and indicates mangrove expansion from 55 ha in 2007 to 125 ha in 2015. Although overall classification accuracy of the 2010 images from October 18 and 23 was higher than 0.9 , the number of mangrove pixels significantly decreased to suggest a negative difference of 20 ha. We ascribed this perceptible difference to the marked, but typical, radiometric defaults of any sun-frontward image configuration, such as observed on the October 18 image. Indeed, this image displays very bright returns from water surfaces and reduced near-infrared contrast in mangrove signatures. The image of July 9, 2009, also acquired under sun-frontward configuration, was less problematic to classify, probably because the tide was low at the time, and it did not produce a visible change in the mangrove area trend (Fig. 5, top). Small decreases in area estimates, reaching 3 ha, were found between October 1 and 16, then October 16 and 23, 2010, and between December 10, 2013 and March 26, 2014.

We were able to use the relatively good performance of the binary supervised classification of "mangrove" versus "non-mangrove" areas to document evolving trends of mangrove extent, even in the complex landscape of the Perancak estuary.

\subsection{Fine-scale evolution of mangrove extent over the whole estuary}

Mangroves have mainly expanded over the central part of the estuary, around the central river catchment, and less in the upstream parts of the estuary. Mangrove expansion (Fig. 5, top) was observed over every landscape unit including natural areas (increase of about $30 \mathrm{ha}$ ), pond floors ( $\sim 5 \mathrm{ha}$ ), and pond walls ( 8 ha). This continuous "greening" has occurred over both pond floors and walls since the end of 2003, whereas mangrove extent seemed to stabilize over unimpeded (natural) areas after 2009.

Ground truth and visual analysis of the satellite image series clearly indicated that most of the plantations were near the center of the estuary extending from both sides of the central road. Additionally, we found several places, distributed along the riverbanks and with a total extent of less than 2 ha, where Rhizophora trees were planted. We decided to combine these 
plantations, outside aquaculture pond walls, with natural mangroves to focus analysis on mangroves planted within pond walls (Fig. 6).

The map of planting years obtained by visual detection of seedling rows, in all images and of all pond floors, indicated that 135 ponds, i.e., a surface area of about 40 ha $(\sim 10 \%$ of the total area of pond floors) have now been planted. The map also showed that plantations made before 2001 (39\%) and in 2008 (51\%) dominated, with 2007 and 2009-2012 accounting for just $1 \%$ and $3 \%$, respectively. This information looks basic but it was unknown before this research.

We used the map of planting years to differentiate the total mangrove extent found in the estuary at different dates into planted and nonplanted mangroves (Fig. 5, bottom). The figure shows that since 2007, coverage of planted mangroves continuously expanded over pond floors (black squares) from about 12 to 35 ha, a mean annual increase of $\sim 3$ ha. Over unimpeded estuarine areas (circles), mangroves naturally expanded from 25 (in 2003) to 48 ha. In addition, both pond floors and walls (green squares) also experienced natural mangrove development from 5 (in 2003) to $\sim 25$ ha (in 2015), corresponding to an expansion rate of $\sim 1.7$ ha/year. Newly formed river islands and banks were also colonized by mangroves with a total increase of $\sim 8$ ha since 2001 (triangles).

\subsection{Monitoring of planted mangroves in disused ponds compared with natural mangroves}

We assessed important characteristics of mangroves planted over pond floors and compared these with the characteristics of natural mangroves growing over unimpeded areas outside pond floors.

\subsubsection{Expansion rates}

We analyzed the evolution of mangrove fraction cover inside each of the 135 ponds that were planted (Fig. 6). As an example, the evolution trends of five ponds are shown in Fig. 7. The canopy of planted stands increases by $10 \%$ (pond 87 planted before 2001) to $20 \%$ (pond 
14 planted in 2008) per year but expansion may stop in areas where seedling disappearance, and thus mortality, is observed. For these latter ponds (e.g., pond 38 planted in 2007), a low expansion rate of $3 \%$ per year stagnates two or three years after the planting date. Over the whole estuary, variability of plantation performance does not suggest any clear spatial patterns reflecting areas that are environmentally less suitable for mangrove growth (Fig. 6). Plantations that experience slow expansion or mortality can be actually found in the neighborhood of ponds demonstrating rapid canopy expansion and at any distance from river channels. Moreover, as observed in several ponds (not shown), canopy gaps, probably the result of illegal logging, could be detected within the year following the event and over areas larger than $100 \mathrm{~m}^{2}$.

\subsubsection{Species composition and regeneration}

Ground truth clearly showed that planted mangrove species were different from the indigenous species that appeared to be naturally present in the estuary, i.e., for which there is little doubt that they were not planted (Supplementary Table 1; Fig. 8, top). Looking at the species composition of adult stages, by considering only the species accounting for more than $10 \%$ of the plot basal area, we found that Rhizophora apiculata, Rhizophora mucronata, and Rhizophora stylosa occurred, respectively, in $53 \%, 40 \%$, and $33 \%$ of the sampled planted ponds. We located and sampled only one Bruguiera gymnorrhiza planted stand (6.7\%). Some Avicennia alba, Avicennia marina, and Sonneratia alba individuals were also recorded inside or at the periphery of the planted Rhizophora stands. Most Avicennia and Sonneratia individuals dominated the plantation canopy. It may be that these latter species were not planted but left in place by planters since they were clearly outside of regular planting rows. In natural areas, Avicennia alba was found in $75 \%$ of the sampled forest plots, Sonneratia alba in 50\%, and Avicennia marina and Avicennia officinalis in $37.5 \%$. We did not record any adult Rhizophora individuals.

Counting of seedlings also generated important baseline information about regeneration capacity in the sampled stands (Supplementary Table 1, column DSPR; Fig. 8, bottom). Although mangrove species have different fruiting periods, we assumed that most of the 
seedlings recorded during May and November 2014 field experiments resulted from propagules released one or two years before. Planted Rhizophora species seemed to not regenerate since we found that Rhizophora apiculata, Rhizophora mucronata and Rhizophora stylosa seedlings accounted for about $1.8 \%, 9.8 \%$ and $5.1 \%$ of the total number of seedlings found in planted areas. By contrast, we observed that about $22 \%$ of the seedlings found in planted areas were Avicennia marina and Bruguiera gymnorrhiza while about $19 \%$ were Ceriops decandra and $10 \%$ were Avicennia alba. Interestingly, this regeneration pattern, in terms of seedling species, was also observed in natural areas. In the unplanted areas, Bruguiera gymnorrhiza and Avicennia marina comprised $35 \%$ and $18 \%$, respectively, with about $11.5 \%$ of Ceriops decandra. A few percent of seedlings in natural areas were also identified, in decreasing order of occurrence, of Avicennia officinalis, Avicennia alba, Rhizophora apiculata, and Sonneratia alba.

\subsubsection{Forest structures}

In planted forest plots, mean quadratic diameter $D q$ values estimated from the measured $\mathrm{DBH}$ of adult planted trees ranged from $2.7 \mathrm{~cm}(\mathrm{P} 7)$ to $10.6 \mathrm{~cm}(\mathrm{P} 3)$, while basal area values varied from $8.1 \mathrm{~m}^{2} \mathrm{ha}^{-1}(\mathrm{P} 7)$ to $33.1 \mathrm{~m}^{2} \mathrm{ha}^{-1}(\mathrm{P} 12)$. In natural mangroves, the range of Dq values varied from $4 \mathrm{~cm}(\mathrm{~N} 3)$ to $18.2 \mathrm{~cm}$ (N8D), while the plot basal area values were between $10 \mathrm{~m}^{2} \mathrm{ha}^{-1}(\mathrm{~N} 3)$ and $23 \mathrm{~m}^{2} \mathrm{ha}^{-1}(\mathrm{~N} 4)$. We calculated that planted trees grew about three times faster in the trunk section than nonplanted trees $\left(\sim 3.2 \mathrm{~m}^{2} \mathrm{ha}^{-1}\right.$ vs. $\left.1.0 \mathrm{~m}^{2} \mathrm{ha}^{-1}\right)$ for each centimeter of DBH increment, in planted and natural stands, respectively. In the field, such structural differences were clearly observable. Planted stands were very dense with only a little sunlight penetrating the canopy whereas the ambient light within natural mangroves was quite high as the trees have larger and more porous crowns. The higher basal area values in planted stands are due to the many basal shoots on Rhizophora trees (Fig. 9). The average number per plot of basal shoots per Rhizophora tree, whether of apiculata, mucronata, or stylosa species, was about four with the highest value exceeding seven. Rhizophora trees with numerous basal shoots looked in poor health with a few leaves at the top of each stem. By 
contrast, even multistemmed Sonneratia alba and Avicennia alba trees had no more than three basal shoots on average per plot, and they did not present dieback signs.

\section{Discussion}

\subsection{Multitemporal very high spatial resolution observations of mangrove changes}

The potential of time series of VHSR images for mangrove management raises issues not yet fully addressed in the literature on mangrove restoration practices. First, the extreme variability of mangrove multispectral signatures across and within the set of images jeopardizes any attempt to establish a classification of all the land covers typical of an estuary, such as pond floors, pond dykes, rivers, and Nypa plantations. Classification accuracy and consistency between acquisition dates depend on both image acquisition parameters (sun, viewing zenith, and azimuth angles) and environmental conditions (tide level, canopy porosity), as emphasized by Viennois et al. (2016) in a study of a preserved mangrove region of Bali. Classification inaccuracy may arise in areas with open canopies where sunlight backscattering from the ground or water surfaces can be significant. Because they amplify sun backscattering by water, sun-frontward angular configurations (such as the October 18, 2010 image) may strongly affect the spectral signatures of any land cover, including mangrove. Their use is therefore not recommended.

The second point is that the robustness of surface area estimation can be evaluated through the multitemporal consistency of image classifications; the number of pixels found for a given class should vary in a balanced way from one image to the next in the time series. In our case, using a supervised classification of "mangrove" and "non-mangrove" areas, pondby-pond evolving trends of mangrove extent and fractional cover were generally consistent. There was additional advantage in combining visual detection of planted ponds, ground truthing, and fine-scale mapping over the whole estuary. The benefits included mapping of plantation ages, identification of planted ponds experiencing mortality, monitoring of expansion rates, and survey of species composition. Our results of mangrove area segmentation over a 
number of years, in both different-aged plantations and natural mangroves, provide a unique dataset for validating any new remote sensing methods which are still needed for mapping mangrove species (Viennois et al. 2016). Methods that combine spectral and textural dimensions of VHSR images (Wang et al. 2016) particularly require to be tested using a large range of canopy textures and spectral responses. Our dataset of mangrove areas includes the homogeneous spectral responses of high-density planted Rhizophora stands, mixed Rhizophora plantations with emerging trees of different species, and natural adult forests with high spectral and textural heterogeneity. Temporal variations of textural and spectral properties of each mangrove area can also be analyzed to evaluate methodological robustness. At present, the use of radiative transfer modeling for interpreting changes in multispectral responses, with varying image acquisition parameters and environmental conditions, remains crucial (Proisy et al. 2016).

\subsection{Present status of mangroves in the Perancak estuary: the example not to follow}

Mangrove areas have been significantly expanding in the Perancak estuary since 2001. Both natural areas and disused ponds surrounded by dykes have experienced revegetation. Unfortunately, a number of our observations indicate that plantation programs in the Perancak estuary have little relation with fundamentals and principles of mangrove ecology (Saenger 2003), hydrology (Alongi and Brinkman 2011) and rehabilitation (Field 1999b; Lewis 2005). They include:

- the planting of exclusively Rhizophora seedlings,

- confining plantations to aquaculture ponds without regard to water fluxes and dyke openings;

- the planting of mangrove species different from indigenous species, i.e., Rhizophora spp. instead of Avicennia spp. or Sonneratia alba;

- congested high planting density, i.e., every $1 \mathrm{~m}$ or $1.5 \mathrm{~m}$;

- the low regeneration capacity in the plantations. 
These observations are not definitive because of the limited number of forest plots inventoried; we did not go everywhere and cannot certify that there is no regeneration at all in planted stands. That said, they suggest a continuous transformation of estuary function toward unpredictable trajectories that could include general outbreaks of insect pests or rapid dieback due to blockage of water flows, as explained by Saenger and Siddiqi (1993).

At the same time, evidence exists that propagules of natural mangrove species can reach and colonize the understory of planted areas connected to water flow through pond dyke openings. This is a good omen for sustainable management. With limited budget, mangrove restoration plans could reach greater efficiency that would just require the opening of sluice gates or breaching of pond dykes at hydrologically strategic locations. The corollary is that maintenance of a continuous network of pond dykes for different land tenure issues is probably the major impediment to sustainable greening of the whole estuary, as pointed out by Di Nitto et al. (2013). The role of plantations in "catalyzing" the recovery of natural forests (Walters 2000) in such fragmented land remains an open question. In the case of the Perancak estuary, we could not comment further the variability of mangrove expansion rate since local microtopography and hydrodynamics inside each pond are not known.

\subsection{Toward a satellite-based monitoring system of mangrove coasts following aquaculture} abandonment

The management of mangrove forests for sustainability is not straightforward (e.g. (Stanley and Lewis 2011), especially after land conversion by aquaculture (Matsui et al. 2010). It requires "a blend of forestry, wetland and ICZM programs", as pointed out by Carter et al. (2015). Very high spatial resolution images can be used as performant and mature tools in order to evaluate mangrove natural capacity of recovery or plantation growth performance. Such satellite observation need be coupled with ground survey of hydrology (Alongi and Brinkman 2011) in the objective of building high resolution hydrodynamic model (Gusmawati 
et al. this issue). In addition, airborne Lidar (light detection and ranging) data should be acquired over aquaculture areas since they proved useful in understanding and monitoring of mangrove colonization processes from fine scale mapping of mangrove canopy and subcanopy topography (Proisy et al. 2009). These points are essential for the success of any restoration program (Ruiz-Jaen and Potvin 2011). Our findings demonstrate that each aquaculture pond has its own disturbance history, environmental conditions, and mangrove growth performance potential. Thus, mangrove management cannot be designed by default, i.e., by the indiscriminant planting of thousands of seedlings, without consideration of suitability and sustainability (Dale et al. 2014; Field 1999a). Gone are the times for such unsustainable practices, because they are now visible from satellite data. In areas abandoned by aquaculture, there is an urgent need for a collegial decision-making process (Clark 1992; White et al. 2005) for selecting among ecosystem services based on conservation, plantation for wood production, or silvo-fishery (Matsui et al. 2014; Ronnback and Primavera 2000; van Oudenhoven et al. 2015b).

As coastal environments are fast changing, prompt action is needed. Embedding costeffective VHSR images into ICZM budgets would allow for the adoption of new management practices, documentation, and then correction of the errors of the past, as well as early warning on eventual mangrove dieback (Lewis et al. 2016). Local management may also require adaptation to climate change as discussed by Peirson et al. (2015). Revegetation of pond walls, as verified by VHSR images, may mitigate $\mathrm{CO}_{2}$ release, as nonvegetated dykes are estimated to have 2.7 times higher release than pond floors (Sidik and Lovelock 2013).

One very positive point that our field survey highlighted is the appeal of fine-scale images and resulting maps to local people, i.e., those involved in the coastal zone management (fishers, NGOs, planters, aquaculture farmers, etc.). They immediately understood the situation. VHSR images play an important role in facilitating and strengthening consensus between ICZM stakeholders with different points of view, levels of appreciation, and means of action (White et al. 2005). In practice, science projects involving VHSR remote sensing could support community-based ecological mangrove restoration (CBEMR) as demonstrated by 
MAP (2017), which in turn may contribute to a better understanding of the complex processes of mangrove rehabilitation in disused ponds.

\subsection{Concluding remarks}

The monitoring of mangrove forests is a prerequisite of any ICZM plan that addresses the complex issue of rehabilitating mangroves in disused aquaculture ponds which is very much linked to ecosystem-based disaster risk reduction (Eco-DRR). The role of VHSR satellite images in this process will increase in parallel with the need for sustainable management of a myriad of ecosystem services in individual mangrove regions. We believe that comprehensive spatial information on mangrove regions could make local communities, and the general public, aware of the degradation of coastal environments since the 1980s due to the unsustainable, short-life-span aquaculture practices and ineffectiveness of many monocultural plantations following aquaculture abandonment. Coastal management is under sentinel watch by VHSR satellite sensors and this should strengthen future decisions.

\section{Acknowledgements}

This work is part of and was funded by the INDESO project (2013-2017) led by the Ministry of Marine Affairs and Fisheries, Indonesia (Balitbang KP; http://www.indeso.web.id). Adewole Olagoke received funding for doctoral studies from the European Commission through the Erasmus Mundus Forest and Nature for Society (FONASO) program.

\section{Appendix A. Supplementary data}

Supplementary data to this article can be found online.

\section{References}

Alongi, D.M. (2002). Present state and future of the world's mangrove forests. Environmental Conservation, 29, 331-349

Alongi, D.M., \& Brinkman, R. (2011). Hydrology and biogeochemistry of mangrove forests. In D.F. Levia, D. Carlyle-Moses \& T. Tanaka (Eds.), Forest hydrology and biogeochemistry: synthesis of past research and future directions (pp. 203-219). Dordrecht: Springer Netherlands

Amir, A.A. (2012). Canopy gaps and the natural regeneration of Matang mangroves. Forest Ecology and Management, 269, 60-67 
Barbier, E.B. (2016). The protective service of mangrove ecosystems: A review of valuation methods. Marine Pollution Bulletin, 109, 676-681

Barbier, E.B., Hacker, S.D., Kennedy, C., Koch, E.W., Stier, A.C., \& Silliman, B.R. (2011). The value of estuarine and coastal ecosystem services. Ecological Monographs, 81, 169-193

Benfield, S.L., Guzman, H.M., \& Mair, J.M. (2005). Temporal mangrove dynamics in relation to coastal development in Pacific Panama. Journal of Environmental Management, 76, 263-276

Bosma, R., Sidik, A.S., Zwieten, P., Aditya, A., \& Visser, L. (2012). Challenges of a transition to a sustainably managed shrimp culture agro-ecosystem in the Mahakam delta, East Kalimantan, Indonesia. Wetlands Ecology and Management, 20, 89-99

Bouchez, A., Pascault, N., Chardon, C., Bouvy, M., Cecchi, P., Lambs, L., Herteman, M., Fromard, F., Got, P., \& Leboulanger, C. (2013). Mangrove microbial diversity and the impact of trophic contamination. Marine Pollution Bulletin, 66, 39-46

Boyd, C.E., \& Clay, J.W. (1998). Shrimp Aquaculture and the Environment. An adviser to shrimp producers and an environmentalist present a prescription for raising shrimp responsibly. Scientific American, June, 58-65

Carter, H., Schmidt, S., \& Hirons, A. (2015). An International Assessment of Mangrove Management: Incorporation in Integrated Coastal Zone Management. Diversity, 7, 74

Check, E. (2005). Natural disasters: Roots of recovery. Nature, 438, 910-911

Clark, J.R. (1992). Integrated management of coastal zones. In, FAO Fisheries Technical Paper, No. 327, 167 pages. $h$ ttp://www.fao.org/docrep/003/t0708e/t0708e00.htm

Costanza, R., de Groot, R., Sutton, P., van der Ploeg, S., Anderson, S.J., Kubiszewski, I., Farber, S., \& Turner, R.K. (2014). Changes in the global value of ecosystem services. Global Environmental Change, 26, 152-158

Dale, P.E.R., Knight, J.M., \& Dwyer, P.G. (2014). Mangrove rehabilitation: a review focusing on ecological and institutional issues. Wetlands Ecology and Management, 22, 587-604

Di Nitto, D., Erftemeijer, P.L.A., van Beek, J.K.L., Dahdouh-Guebas, F., Higazi, L., Quisthoudt, K., Jayatissa, L.P., \& Koedam, N. (2013). Modelling drivers of mangrove propagule dispersal and restoration of abandoned shrimp farms. Biogeosciences, 10, 5095-5113

Duke, N.C., Meynecke, J.O., Dittmann, S., Ellison, A.M., Anger, K., Berger, U., Cannicci, S., Diele, K., Ewel, K.C., Field, C.D., Koedam, N., Lee, S.Y., Marchand, C., Nordhaus, I., \& Dahdouh-Guebas, F. (2007). A world without mangroves? Science, 317, 41-42

Duncan, C., Primavera, J.H., Pettorelli, N., Thompson, J.R., Loma, R.J.A., \& Koldewey, H.J. (2016). Rehabilitating mangrove ecosystem services: A case study on the relative benefits of abandoned pond reversion from Panay Island, Philippines. Marine Pollution Bulletin, 109, 772-782

Dutrieux, E., Proisy, C., Fromard, F., Walcker, R., Ilman, M., Pawlowski, F., Ferdiansyah, H., \& Ponthieux, O. (2014). Mangrove restoration in the vicinity of oil and gas facilities: lessons learnt from a large scale project. In, 2014 SPE Conference on Health, Safety, and Environment. Long Beach, California, USA

Field, C.D. (1999a). Mangrove rehabilitation: choice and necessity. Hydrobiologia, 413, 47-52

Field, C.D. (1999b). Rehabilitation of Mangrove Ecosystems: An Overview. Marine Pollution Bulletin, $37,383-392$

Friess, D.A., Lee, S.Y., \& Primavera, J.H. (2016). Turning the tide on mangrove loss. Marine Pollution Bulletin, 109, 673-675

Giri, C., Long, J., Abbas, S., Murali, R.M., Qamer, F.M., Pengra, B., \& Thau, D. (2015). Distribution and dynamics of mangrove forests of South Asia. Journal of Environmental Management, 148, 101-111

Gusmawati, N., Soulard, B., Selmaoui-Folcher, N., Proisy, C., Mustafa, A., Le Gendre, R., Laugier, T., \& Lemonnier, H. (this issue). Surveying shrimp aquaculture pond activity using multitemporal VHSR satellite images - case study from the Perancak estuary, Bali, Indonesia. Marine Pollution Bulletin, $x x x x$

IIman, M., Dargusch, P., Dart, P., \& Onrizal (2016). A historical analysis of the drivers of loss and degradation of Indonesia's mangroves. Land Use Policy, 54, 448-459

Kuenzer, C., Bluemel, A., Gebhardt, S., Quoc, T.V., \& Dech, S. (2011). Remote sensing of mangrove ecosystems: A review. Remote Sensing, 3, 878-928

Lewis, R.R. (2005). Ecological engineering for successful management and restoration of mangrove forests. Ecological Engineering, 24, 403-418

Lewis, R.R. (2009). Knowledge overload, wisdom underload. Ecological Engineering, 35, 341-342

Lewis, R.R., Milbrandt, E.C., Brown, B., Krauss, K.W., Rovai, A.S., Beever lii, J.W., \& Flynn, L.L. (2016). Stress in mangrove forests: Early detection and preemptive rehabilitation are essential for future successful worldwide mangrove forest management. Marine Pollution Bulletin 
Lovelock, C.E., Cahoon, D.R., Friess, D.A., Guntenspergen, G.R., Krauss, K.W., Reef, R., Rogers, K., Saunders, M.L., Sidik, F., Swales, A., Saintilan, N., Thuyen, L.X., \& Triet, T. (2015). The vulnerability of Indo-Pacific mangrove forests to sea-level rise. Nature, 526, 559-563

MAP (2017). Mangrove Action Project, CBEMR: A Successful Method of Mangrove Restoration. http://www. mangroveactionproject.org/cbemr/

Matsui, N., Songsangjinda, P., \& Wodehouse, D. (2014). Longevity of simultaneous operation of aquaculture and mangrove forestry as explained in terms of water and sediment qualities. Wetlands Ecology and Management, 22, 215-225

Matsui, N., Suekuni, J., Nogami, M., Havanond, S., \& Salikul, P. (2010). Mangrove rehabilitation dynamics and soil organic carbon changes as a result of full hydraulic restoration and re-grading of a previously intensively managed shrimp pond. Wetlands Ecology and Management, 18, 233-242

Oliver, T.S.N., Rogers, K., Chafer, C.J., \& Woodroffe, C.D. (2012). Measuring, mapping and modelling: an integrated approach to the management of mangrove and saltmarsh in the Minnamurra River estuary, southeast Australia. Wetlands Ecology and Management, 20, 353-371

Peirson, W., Davey, E., Jones, A., Hadwen, W., Bishop, K., Beger, M., Capon, S., Fairweather, P., Creese, B., Smith, T.F., Gray, L., \& Tomlinson, R. (2015). Opportunistic management of estuaries under climate change: A new adaptive decision-making framework and its practical application. Journal of Environmental Management, 163, 214-223

Primavera, J.H., dela Cruz, M., Montilijao, C., Consunji, H., dela Paz, M., Rollon, R.N., Maranan, K., Samson, M.S., \& Blanco, A. (2016). Preliminary assessment of post-Haiyan mangrove damage and short-term recovery in Eastern Samar, central Philippines. Marine Pollution Bulletin, 109, 744-750

Primavera, J.H., \& Esteban, J.M.A. (2008). A review of mangrove rehabilitation in the Philippines: successes, failures and future prospects. Wetlands Ecology and Management, 16, 345-358

Proisy, C., Couteron, P., \& Fromard, F. (2007). Predicting and mapping mangrove biomass from canopy grain analysis using Fourier-based textural ordination of IKONOS images. Remote Sensing of Environment, 109, 379-392

Proisy, C., Féret, J.-B., Lauret, N., \& Gastellu-Etchegorry, J.-P. (2016). Mangrove forest dynamics using very high spatial resolution optical remote sensing. In N.N. Baghdadi \& M. Zribi (Eds.), Remote sensing of Land surfaces: Urban and coastal area, Chapter 7, Volume 5, 269-295. Paris: Elsevier, ISBN: 9780081017678

Proisy, C., Gratiot, N., Anthony, E.J., Gardel, A., Fromard, F., \& Heuret, P. (2009). Mud bank colonization by opportunistic mangroves: A case study from French Guiana using lidar data. Continental Shelf Research, 29, 632-641

Rahman, A.F., Dragoni, D., Didan, K., Barreto-Munoz, A., \& Hutabarat, J.A. (2013). Detecting large scale conversion of mangroves to aquaculture with change point and mixed-pixel analyses of highfidelity MODIS data. Remote Sensing of Environment, 130, 96-107

Rapinel, S., Clément, B., Magnanon, S., Sellin, V., \& Hubert-Moy, L. (2014). Identification and mapping of natural vegetation on a coastal site using a Worldview-2 satellite image. Journal of Environmental Management, 144, 236-246

Richards, D.R., \& Friess, D.A. (2016). Rates and drivers of mangrove deforestation in Southeast Asia, 2000-2012. Proceedings of the National Academy of Sciences, 113, 344-349

Ronnback, P., \& Primavera, J.H. (2000). Illuminating the need for ecological knowledge in economic valuation of mangroves under different management regimes - a critique. Ecological Economics, 35, $135-141$

Ruiz-Jaen, M.C., \& Potvin, C. (2011). Can we predict carbon stocks in tropical ecosystems from tree diversity? Comparing species and functional diversity in a plantation and a natural forest. New Phytologist, 189, 978-987

Saenger, P. (2003). Mangrove Ecology, Silviculture and Conservation. Dordrecht, NL: Kluwer Academic Publishers

Saenger, P., \& Siddiqi, N.A. (1993). Land from the sea: The mangrove afforestation program of Bangladesh. Ocean \& Coastal Management, 20, 23-39

Samson, M.S., \& Rollon, R.N. (2008). Growth performance of planted red mangroves in the Philippines: revisiting forest management strategies. Ambio, 37, 234-240

Sathirathai, S. (1998). Economic valuation of mangroves and the roles of local communities in the conservation of natural resources: case study of Surat Thani, South of Thailand: Economy and environment program for Southeast Asia research report series. Economy and Environment Program for Southeast Asia, South Bridge

Sidik, F., \& Lovelock, C.E. (2013). CO2 efflux from shrimp ponds in Indonesia. PLoS ONE, 8, e66329

Stanley, O.D., \& Lewis, R.R. (2011). Strategies for mangrove rehabilitation in an eroded coastline of Selangor, Peninsular Malaysia 
Stevenson, N., Lewis, R.R., \& Burbridge, P.R. (1999). Disused shrimp ponds and mangrove rehabilitation. In W.J. Streever (Ed.), An International Perspective on Wetland Rehabilitation (pp. 277-297): Kluwer Academic Publishers, The Netherlands, 338 pp.

Valiela, I., Bowen, J.L., \& York, J.K. (2001). Mangrove forests: One of the world's threatened major tropical environments. BioScience, 51, 807-815

van Oudenhoven, A.P.E., Siahainenia, A.J., I. Sualia, I., Tonneijck, F.H., Van der Ploeg, S., \& de Groot, R.S. (2015a). Effects of different management regimes on mangrove ecosystem services in Java, Indonesia. In, Technical paper for the 'Mangrove Capital' project: Wageningen University (Environmental Systems Analysis Group, Wageningen)

van Oudenhoven, A.P.E., Siahainenia, A.J., Sualia, I., Tonneijck, F.H., van der Ploeg, S., de Groot, R.S., Alkemade, R., \& Leemans, R. (2015b). Effects of different management regimes on mangrove ecosystem services in Java, Indonesia. Ocean \& Coastal Management, 116, 353-367

Viennois, G., Proisy, C., Feret, J.-B., Prosperi, J., Sidik, F., Suhardjono, Rahmania, R., Longépé, N., Germain, O., \& Gaspar, P. (2016). Multitemporal analysis of high spatial resolution satellite imagery for mangrove species mapping, Bali, Indonesia. leee Journal of Selected Topics in Applied Earth Observations and Remote Sensing, 9, 3680-3686

Walters, B.B. (2000). Local mangrove planting in the Philippines: Are fisherfolk and fishpond owners effective restorationists? Restoration Ecology, 8, 237-246

Wang, T., Zhang, H., Lin, H., \& Fang, C. (2016). Textural-spectral feature-based species classification of mangroves in Mai Po Nature Reserve from Worldview-3 imagery. Remote Sensing, 8, 1-15

White, A.T., Christie, P., D’Agnes, H., Lowry, K., \& Milne, N. (2005). Designing ICM projects for sustainability: Lessons from the Philippines and Indonesia. Ocean \& Coastal Management, 48, 271296

Wilkinson, G.G. (2005). Results and implications of a study of fifteen years of satellite image classification experiments. IEEE Transactions on Geoscience and Remote Sensing, 43, 433-440

Zhou, J., Proisy, C., Descombes, X., le Maire, G., Nouvellon, Y., Stape, J.-L., Viennois, G., Zerubia, J., \& Couteron, P. (2013). Mapping local density of young Eucalyptus plantations by individual tree detection in high spatial resolution satellite images. Forest Ecology and Management, 301, 129-141 
Fig. 1. Gray-scale image excerpts of $350 \mathrm{~m} \times 250 \mathrm{~m}$ over disused and mangrove-vegetated ponds, Perancak estuary, Bali, Indonesia. Image pixel size, satellite platform, channel (PAN: panchromatic; NIR: near-infrared), and date of acquisition are indicated in the top right corner.
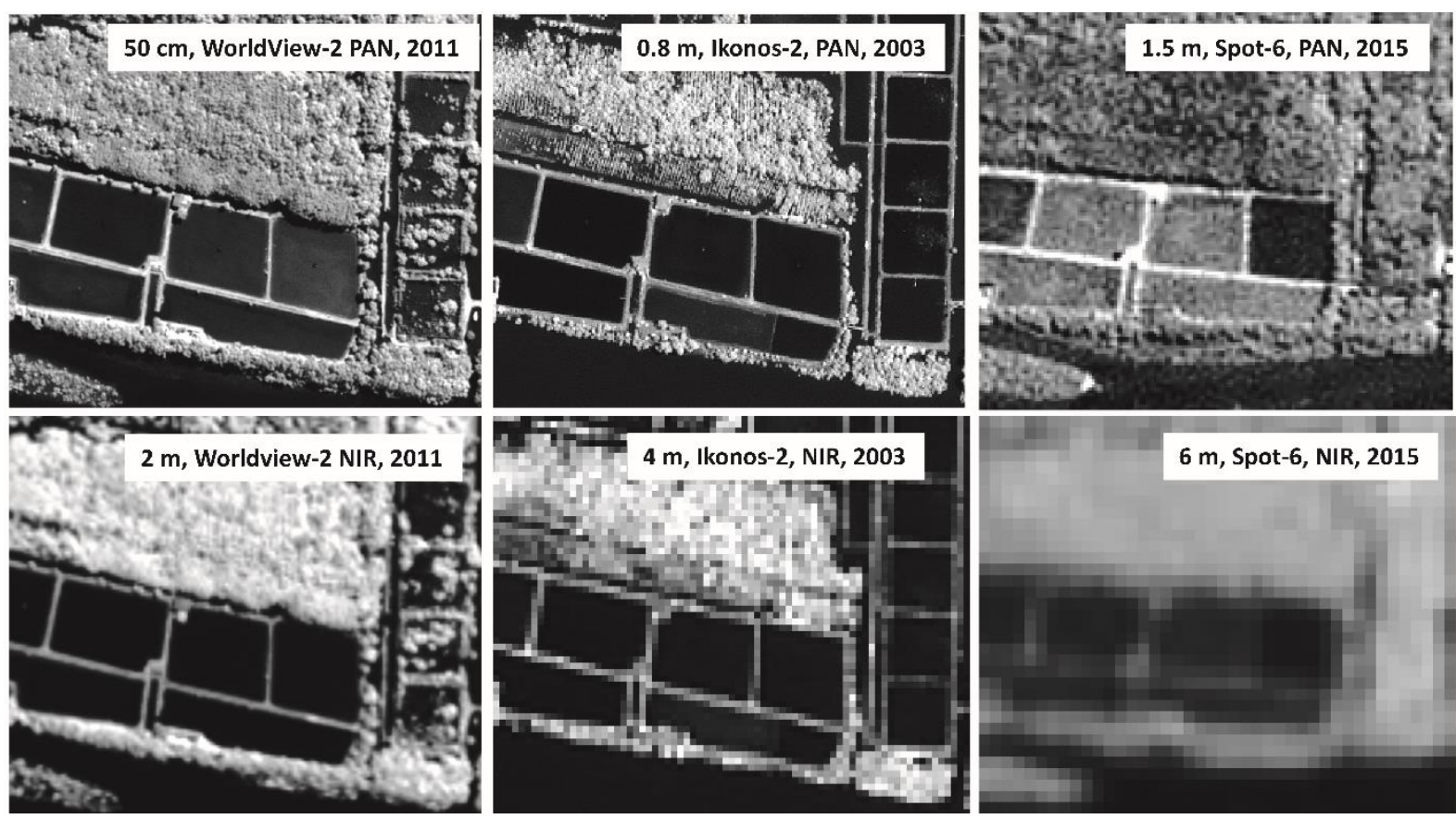
Fig. 2. Location of the Perancak estuary, west Bali, Indonesia (A and B). The Perancak estuary is a fragmented area consisting of different land cover units including aquaculture ponds, plantations of Nypa fruticans, infrastructure, rivers, and main water channels (C). Remaining areas (in white color) inside the estuary limit correspond to unimpeded "natural" areas with a direct link to flooding waters. The bottom left inset (D) shows a $500 \mathrm{~m}$ large pond-fragmented area.
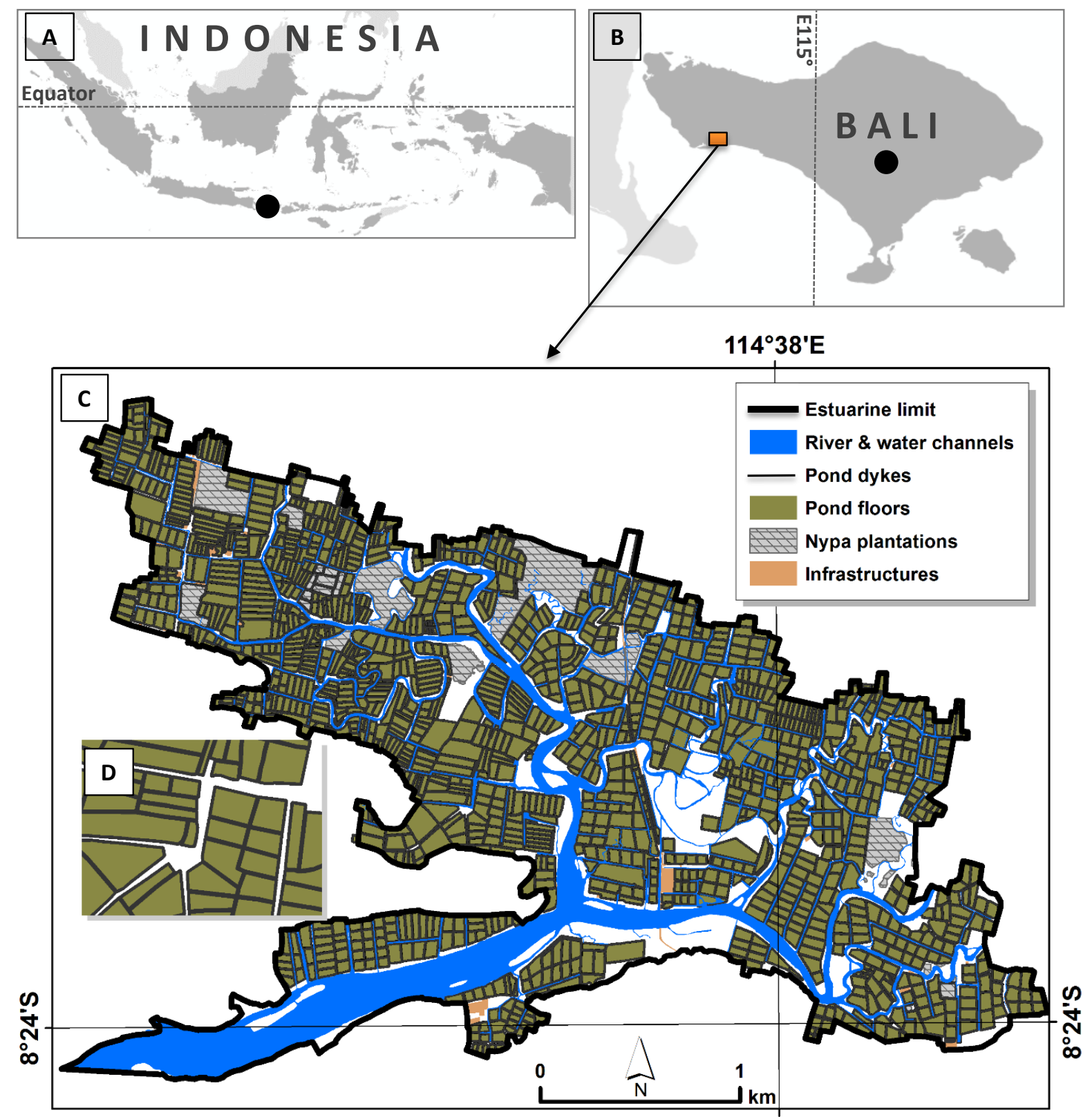

$114^{\circ} 38^{\prime} \mathrm{E}$ 
Fig. 3. Flowchart of combined ground and VHSR satellite image processing and analysis for monitoring mangroves at fine scales.

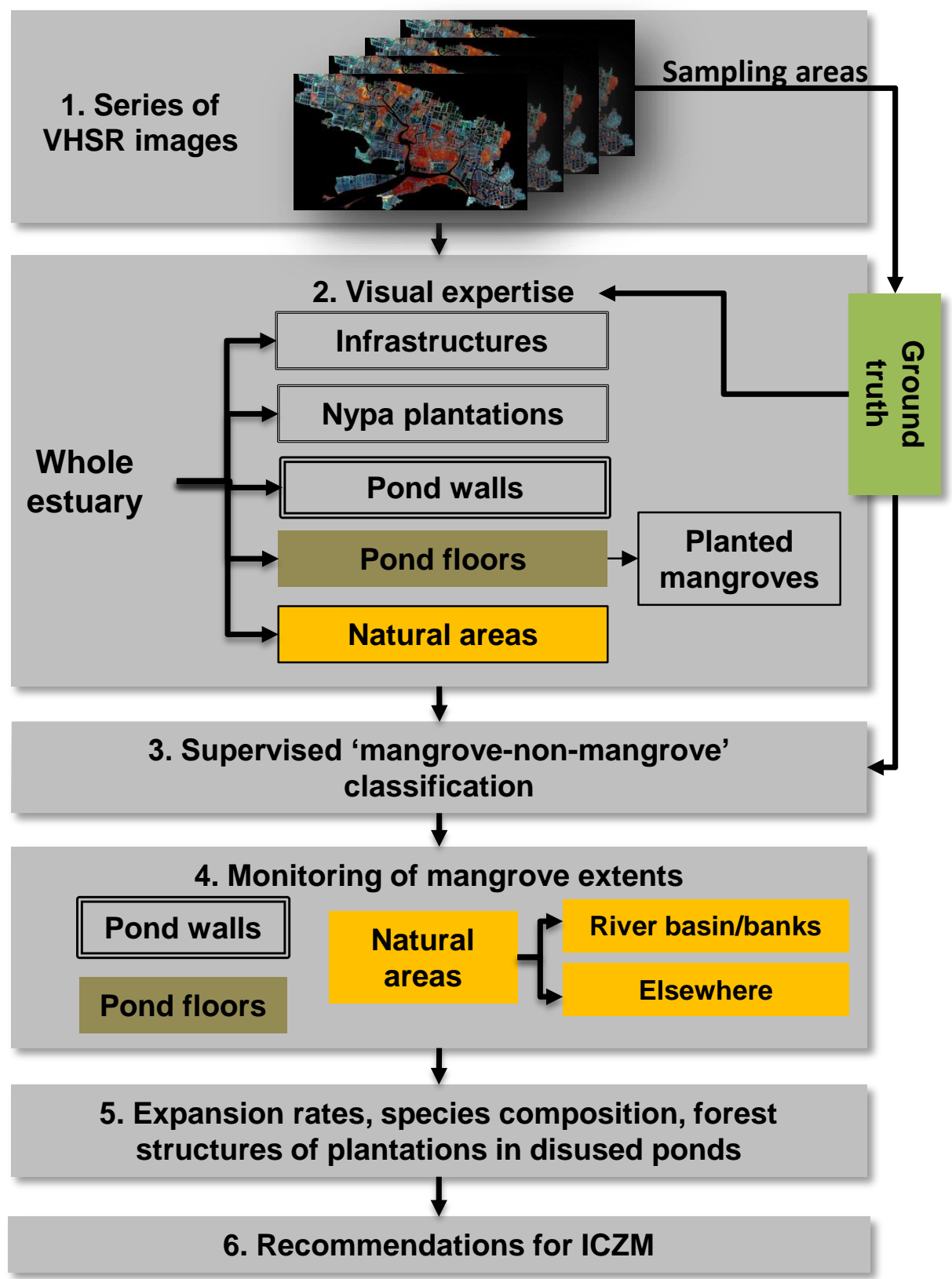


Fig. 4. Illustration of the potential of VHSR images for visual detection of "just planted" ponds. Two $70 \mathrm{~m} \times 60 \mathrm{~m}$ image excerpts acquired in October 2014 (A) and in April 2015 (B), before and after the date of planting Rhizophora seedlings. Field photograph taken on November 18, 2014 (C) showing seedlings and thus indicating that the planting was carried out at the end of October or early November 2014.

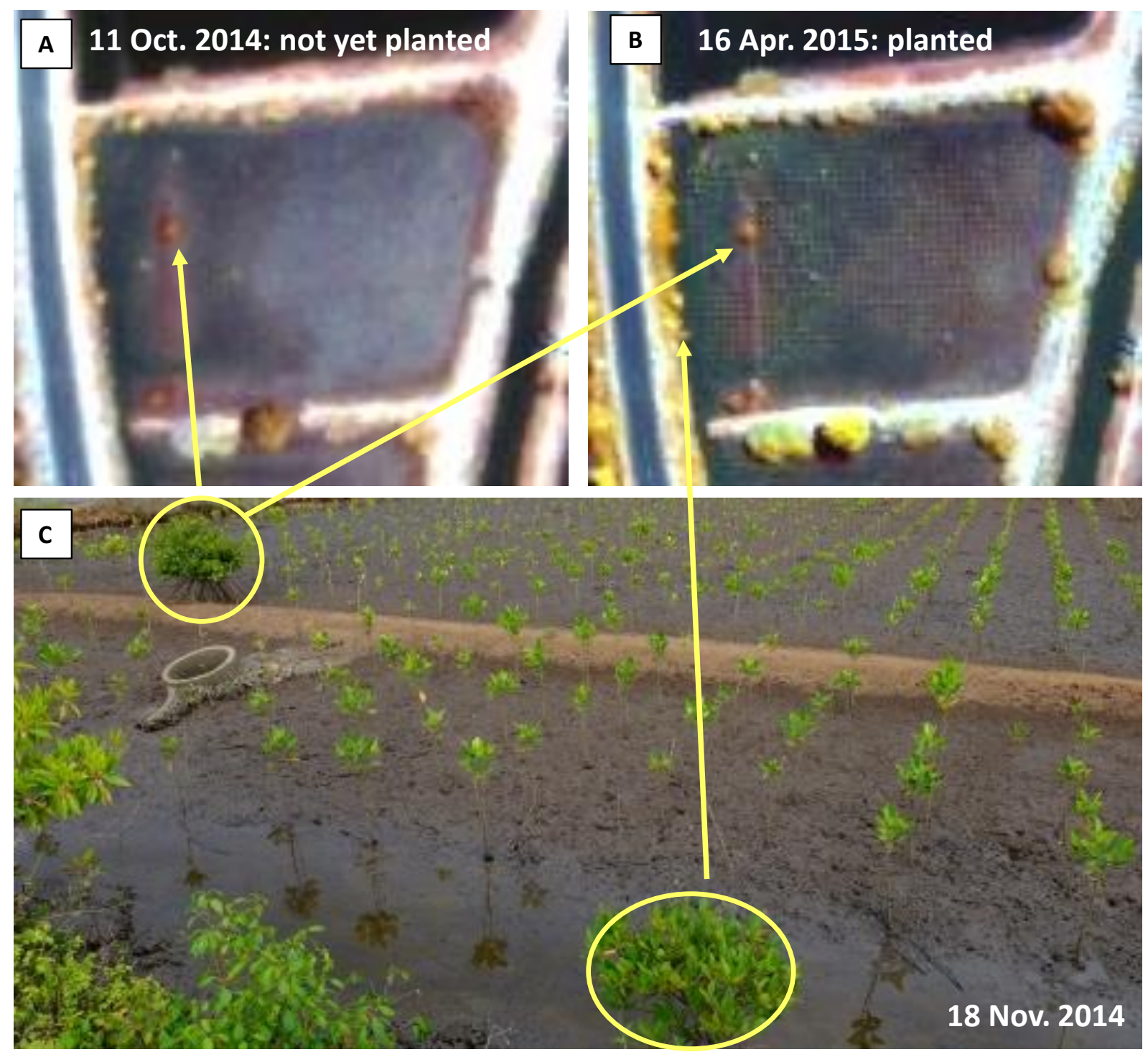


Fig. 5. Trends of mangrove area extent in the Perancak estuary between 2001 and 2015. Top: mangrove land uses on natural areas (outside the pond walls), pond floors, and pond walls. Bottom: comparison of occupancy rates between planted and natural (nonplanted) mangroves on ponds, rivers islands, and banks, and other natural areas (denoted as "elsewhere").
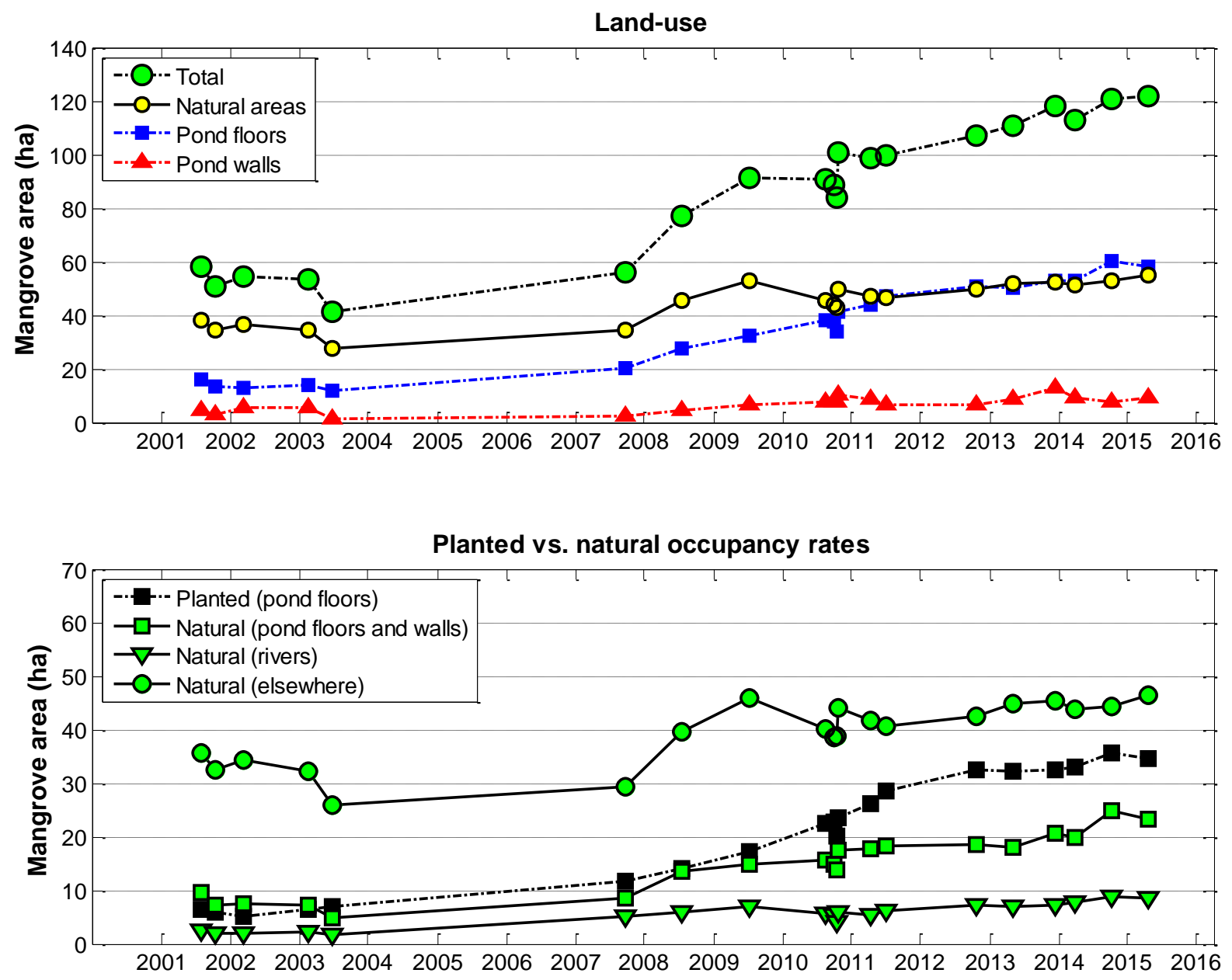
Fig. 6. Map showing the planted aquaculture ponds, the years of plantation, and a fraction cover index: Low (<50\%), Partial (50-90\%), and Full (>90\%).

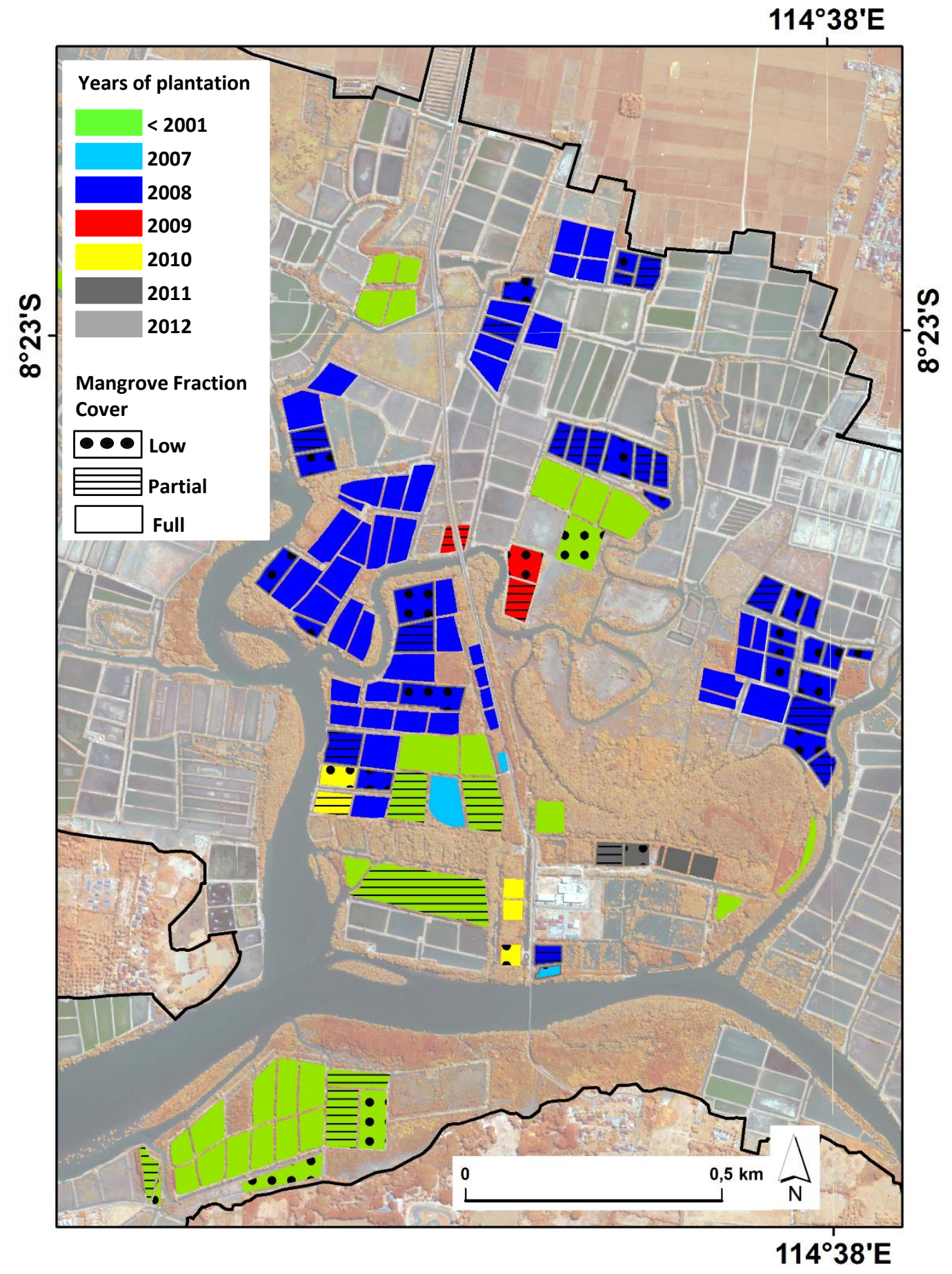


Fig. 7. Mangrove fraction cover changes for different-aged plantations growing on five different pond floors.

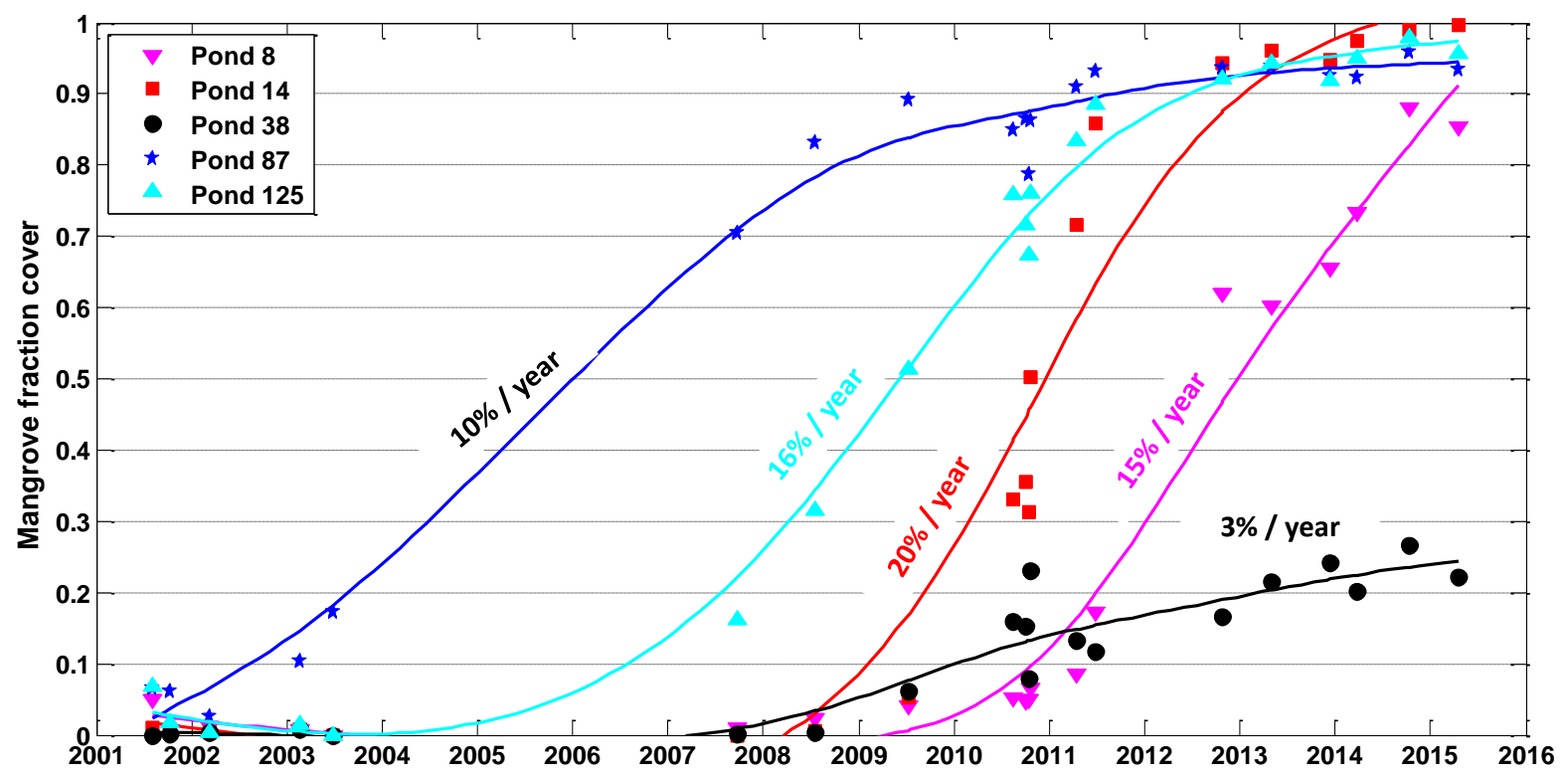


Fig. 8. Occurrence of mangrove species in sampled areas both planted and natural: adult (top) and regeneration (bottom). For adult stages, percentage values along each species axis correspond to the chances of having trees of that species with basal area $>10 \%$ of the total plot basal area (see column DSP of Supplementary Table 1). For regeneration stages, percentage values correspond to the chances of having (nonplanted) regeneration seedlings of a given species in planted and natural areas (Supplementary Table 1, column DSPR). We only showed the species with percentage values of occurrence greater that $2 \%$. They are distributed in alphabetical order, from Avicennia alba (Aa) to Sonneratia alba (Sa) counterclockwise. The acronyms Am, Ao, Bg, Bs, Ra, Rm, Rs correspond to Avicennia marina, Avicennia officinalis, Bruguiera gymnorrhiza, Bruguiera sexangula, Rhizophora apiculata, Rhizophora mucronata, and Rhizophora stylosa. 


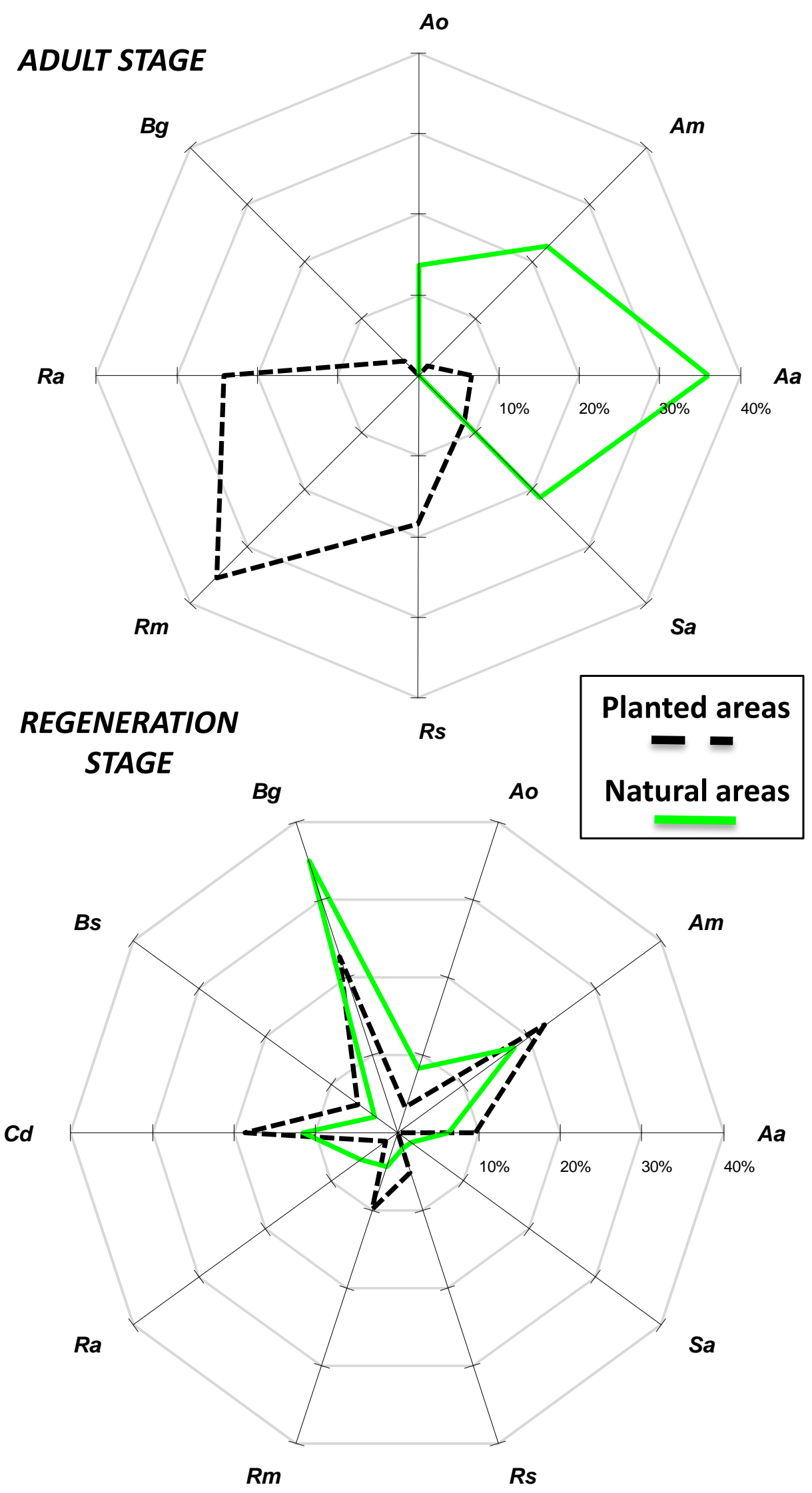


Fig. 9. Average number of basal shoots per individual tree versus tree DBH (top). A typical Rhizophora plantation with multiple basal shoots for each individual (bottom).
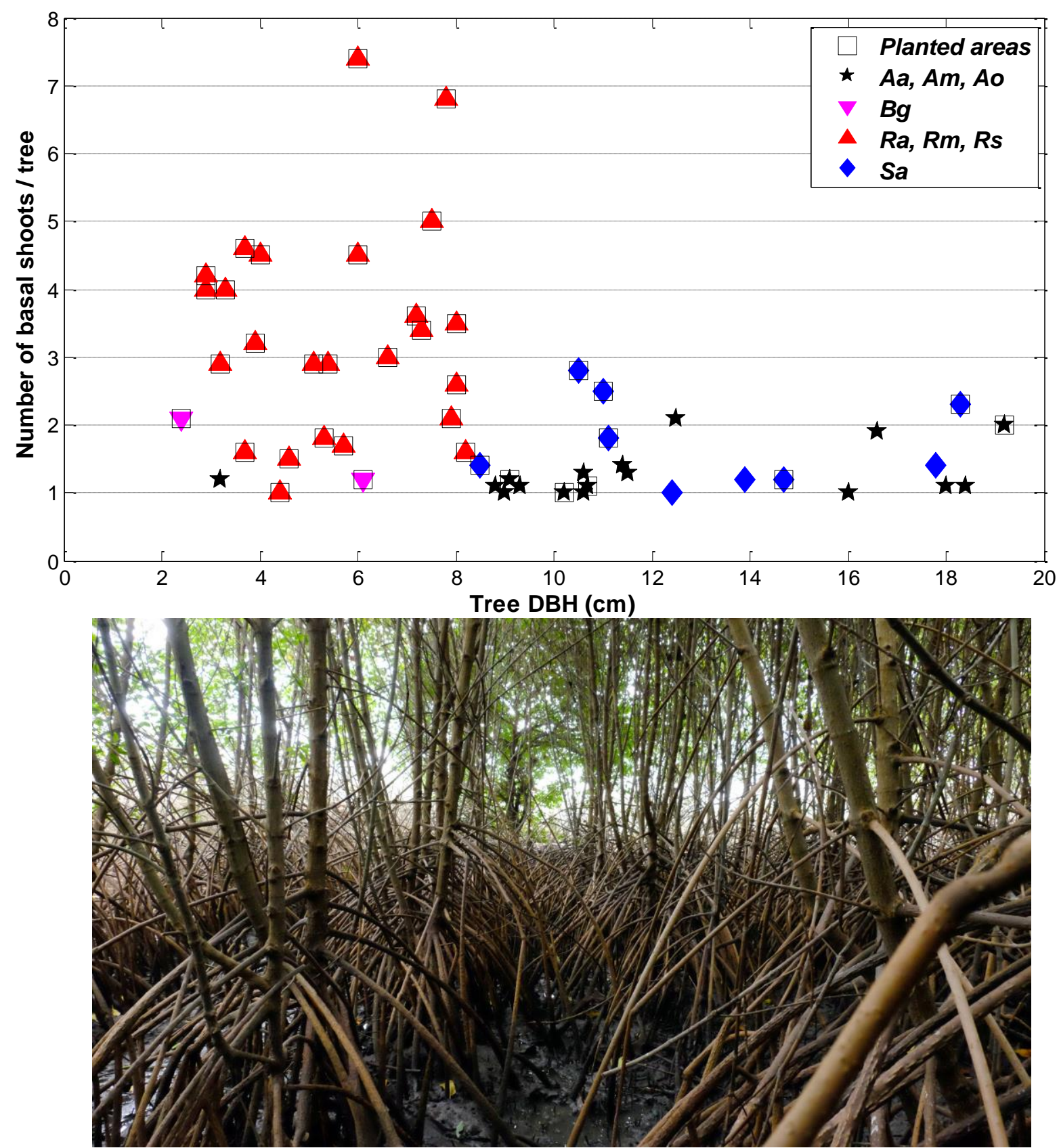
Supplementary Figure 1. Location of forest plots (yellow squares), sites of diameters at breast height $(\mathrm{DBH})$ records (dark stars), and places of observations (check marks).

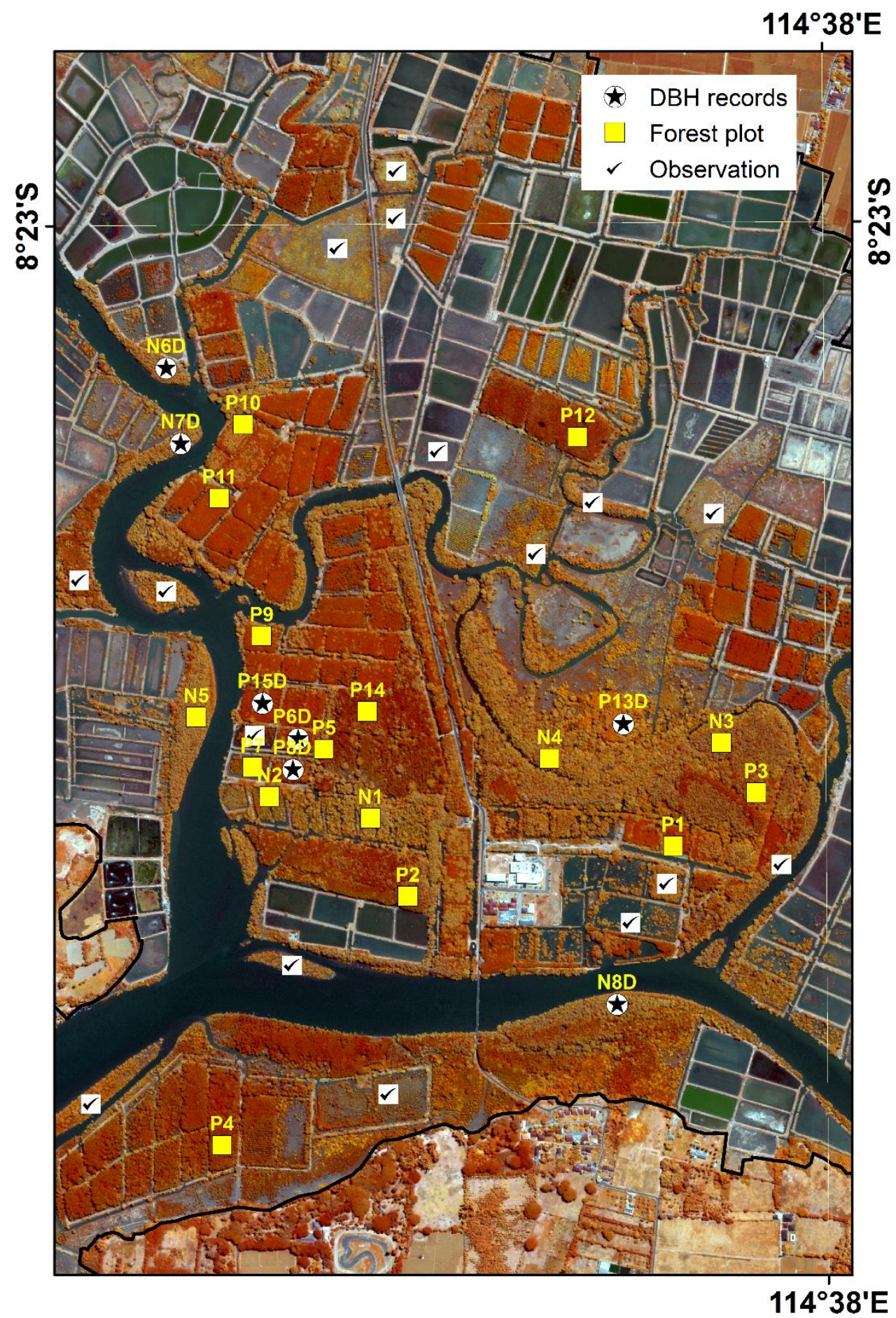


Supplementary Table 1. Forest data collected in planted (PlotID starting with "P") and natural (PlotID starting with "N") areas. A PlotID terminated by "D" identifies forest data collected in sites of DBH records (dark stars in the Supplementary Table 1). NSP corresponds to the total number of species of adult trees. $D q$ is the mean quadratic diameter. $G$ is the plot basal area. $N$ is either the number of individual trees/ha or the number of trees measured. $\mathrm{H}$ is the canopy height formed by dominant trees. DSP indicates the adult tree species that count for $>10 \%$ of $G$ while $D S P R$ gives the species whose number of regeneration seedlings was $>5 \%$ of the total number of seedlings found in the plot. $D B H m$ indicates the average trunk diameter and its range of variation in the dominant species. $\mathrm{G} \%$ and $\mathrm{N} \%$ are the relative proportions of trees of a given species. NStt is the average number of basal shoots by individuals of a given species. 


\begin{tabular}{|c|c|c|c|c|c|c|c|c|c|c|c|c|}
\hline PlotID & $\begin{array}{l}\text { Area } \\
\left(\mathrm{m}^{2}\right)\end{array}$ & NSP & $\begin{array}{l}\text { Dq } \\
(\mathrm{cm})\end{array}$ & $\begin{array}{c}\mathbf{G} \\
\left(m^{2} \cdot h a^{-1}\right. \\
\left.o r m^{2}\right)\end{array}$ & $\begin{array}{c}\mathbf{N} \\
\text { (\#/ha } \\
\text { or \#) }\end{array}$ & $\begin{array}{c}\mathbf{H} \\
(m)\end{array}$ & $\begin{array}{c}\text { DSP } \\
\text { G>10 } \\
\% \\
\end{array}$ & $\begin{array}{c}\text { DSPR } \\
\mathrm{Nr}>5 \%\end{array}$ & $\begin{array}{l}\text { DBHm } \\
(\mathrm{cm})\end{array}$ & G\% & $\mathrm{N} \%$ & NStt \\
\hline P1 & 100 & 1 & 3.8 & 8.5 & 5000 & 6 & $\mathrm{Rm}$ & Nothing & $3.7+-1.0$ & 100 & 100 & 1.6 \\
\hline \multirow[t]{3}{*}{ P2 } & 400 & 7 & 8.0 & 27.2 & 2725 & 13 & $\mathrm{Ra}$ & & $7.9+-2.3$ & 69 & 65 & 2.1 \\
\hline & & & & & & & $\mathrm{Rm}$ & Nothing & $8.0+-1.3$ & 11 & 7 & 2.6 \\
\hline & & & & & & & Sa & & $11.1+-4.5$ & 14 & 6 & 1.8 \\
\hline \multirow[t]{3}{*}{ P3 } & 400 & 4 & 10.6 & 28.2 & 1325 & 18 & $\mathrm{Am}$ & & $10.7+-3.7$ & 18 & 34 & 1.1 \\
\hline & & & & & & & $\mathrm{Ra}$ & Nothing & $7.2+-1.5$ & 38 & 45 & 3.6 \\
\hline & & & & & & & Sa & & $18.3+-5.5$ & 35 & 11 & 2.3 \\
\hline \multirow[t]{2}{*}{ P4 } & 625 & 4 & 7.1 & 21.0 & 752 & 13 & $\mathrm{Rm}$ & $\mathrm{Ra}, \mathrm{Rm}$, & $7.8+-0.9$ & 72 & 60 & 6.8 \\
\hline & & & & & & & Rs & Rs & $6.0+-1.0$ & 22 & 28 & 7.4 \\
\hline \multirow[t]{3}{*}{ P5 } & 200 & 5 & 10.2 & 27.7 & 1400 & 19 & Ra & & $8.0+-1.6$ & 53 & 57 & 3.5 \\
\hline & & & & & & & Rs & Am, Ao & $7.5+-2.3$ & 17 & 14 & 5.0 \\
\hline & & & & & & & Sa & & $14.7+-9.8$ & 28 & 18 & 1.2 \\
\hline \multirow[t]{5}{*}{ P6D } & & 6 & 5.4 & 0.4 & 100 & 7 & $\mathrm{Aa}$ & & $9.1+-2.3$ & 22 & 11 & 1.2 \\
\hline & & & & & & & Ra & & $3.2+-0.9$ & 25 & 43 & 2.9 \\
\hline & & & & & & & $\mathrm{Rm}$ & Nothing & $5.1+-0.8$ & 14 & 10 & 2.9 \\
\hline & & & & & & & Rs & & $4.6+-1.0$ & 14 & 23 & 1.5 \\
\hline & & & & & & & Sa & & $8.5+-5.6$ & 18 & 5 & 1.4 \\
\hline \multirow[t]{3}{*}{ P7 } & 100 & 5 & 2.7 & 8.1 & 4700 & 3 & $\mathrm{Bg}$ & & $2.4+-0.9$ & 27 & 51 & 2.1 \\
\hline & & & & & & & $\mathrm{Ra}$ & Nothing & $3.3+-1.1$ & 22 & 9 & 4.0 \\
\hline & & & & & & & Rs & & $2.9+-0.8$ & 47 & 28 & 4.0 \\
\hline \multirow[t]{2}{*}{ P8D } & & 6 & 3.4 & 0.3 & 100 & 7 & Ra & Nothing & $2.9+-0.8$ & 63 & 67 & 4.2 \\
\hline & & & & & & & $\mathrm{Rm}$ & Notning & $4.0+-1.0$ & 26 & 15 & 4.5 \\
\hline P9 & 450 & 3 & 5.9 & 9.5 & 2222 & 9 & $\mathrm{Rm}$ & Nothing & $5.7+-1.3$ & 94 & 94 & 1.7 \\
\hline \multirow[t]{2}{*}{ P10 } & 400 & 4 & 7.2 & 20.2 & 4875 & 12 & $\mathrm{Aa}$ & $\mathrm{Am}$ & $10.2+-2.7$ & 72 & 33 & 1.0 \\
\hline & & & & & & & $\mathrm{Rm}$ & $\mathrm{Am}$ & $4.4+-1.5$ & 25 & 61 & 1.0 \\
\hline \multirow[t]{2}{*}{ P11 } & 100 & 3 & 5.5 & 22.7 & 3900 & 11 & $\mathrm{Rm}$ & $\mathrm{Aa}, \mathrm{Am}$, & $5.4+-1.2$ & 88 & 82 & 2.9 \\
\hline & & & & & & & Rs & $\mathrm{Bg}$ & $5.3+-1.0$ & 11 & 15 & 1.8 \\
\hline \multirow[t]{2}{*}{ P12 } & 400 & 3 & 7.0 & 33.1 & 3225 & 13 & $\mathrm{Ra}$ & Nothing & $8.2+-2.1$ & 15 & 16 & 1.6 \\
\hline & & & & & & & Rs & Notning & $6.6+-1.6$ & 85 & 82 & 3.0 \\
\hline \multirow[t]{3}{*}{ P13D } & & 4 & 6.8 & 0.5 & 116 & 10 & $\mathrm{Aa}$ & & $19.2+-0.0$ & 11 & 1 & 2.0 \\
\hline & & & & & & & Ao & $\mathrm{Bg}$ & $21.0+-0.0$ & 13 & 1 & 2.0 \\
\hline & & & & & & & $\mathrm{Bg}$ & & $6.1+-1.3$ & 74 & 97 & 1.2 \\
\hline \multirow[t]{3}{*}{ P14 } & 400 & 6 & 6.8 & 19.3 & 1450 & 10 & Ra & & $6.0+-1.1$ & 68 & 69 & 4.5 \\
\hline & & & & & & & Rs & Nothing & $7.3+-2.7$ & 20 & 17 & 3.4 \\
\hline & & & & & & & Sa & & $11.0+-3.7$ & 11 & 7 & 2.5 \\
\hline \multirow[t]{3}{*}{ P15D } & & 8 & 4.8 & 0.5 & 100 & 7 & $\mathrm{Ra}$ & & $3.7+-0.9$ & 34 & 32 & 4.6 \\
\hline & & & & & & & Rs & Nothing & $3.9+-0.9$ & 32 & 42 & 3.2 \\
\hline & & & & & & & Sa & & $10.5+-6.4$ & 20 & 4 & 2.8 \\
\hline \multirow[t]{2}{*}{ N1 } & 500 & 4 & 10.6 & 16.1 & 1440 & 14 & $\mathrm{Aa}$ & $\mathrm{Am} \mathrm{B \sigma}$ & $11.4+-2.8$ & 73 & 54 & 1.4 \\
\hline & & & & & & & $\mathrm{Am}$ & Am, Bg & $8.8+-3.6$ & 14 & 22 & 1.1 \\
\hline \multirow[t]{2}{*}{ N2 } & 100 & 3 & 4.0 & 10.0 & 6500 & 7 & $\mathrm{Am}$ & & $3.2+-1.9$ & 87 & 95 & 1.2 \\
\hline & & & & & & & Sa & $3 g$ & $12.4+-0.0$ & 12 & 2 & 1.0 \\
\hline N3 & 2500 & 6 & 16.0 & 23.1 & 736 & 20 & Ao & $\mathrm{Aa}, \mathrm{Am}$, & $12.5+-5.3$ & 26 & 20 & 2.1 \\
\hline & & & & & & & Sa & $\mathrm{Ao}, \mathrm{Ra}$, & $17.8+-5.2$ & 67 & 57 & 1.4 \\
\hline N4 & 900 & 7 & 14.8 & 18.9 & 800 & 20 & $\mathrm{Aa}$ & & $11.5+-4.3$ & 24 & 38 & 1.3 \\
\hline & & & & & & & Ao & Ao, Bg & $16.6+-7.6$ & 42 & 19 & 1.9 \\
\hline & & & & & & & Sa & & $20.5+-10 . \subseteq$ & 28 & 15 & 1.2 \\
\hline N5 & 400 & 6 & 11.2 & 16.4 & 1550 & 13 & $\mathrm{Aa}$ & $\mathrm{Ao}, \mathrm{Bg}$ & $10.6+-4.0$ & 83 & 85 & 1.0 \\
\hline & & & & & & & $\mathrm{Am}$ & $\mathrm{Rm}$ & $10.6+-6.7$ & 12 & 6 & 1.3 \\
\hline N6D & & 1 & 18.7 & 0.6 & 20 & 10 & $\mathrm{Aa}$ & $\mathrm{Aa}$ & $18.4+-3.5$ & 100 & 100 & 1.1 \\
\hline N7D & & 2 & 18.2 & 1.0 & 36 & 12 & $\mathrm{Aa}$ & Aa. Am & $16.0+-2.3$ & 17 & 22 & 1.0 \\
\hline & & & & & & & Ao & $\mathrm{Aa}, \mathrm{Am}$ & $18.0+-5.3$ & 83 & 78 & 1.1 \\
\hline N8D & & 3 & 11.1 & 1.1 & 100 & 13 & $\mathrm{Aa}$ & & $9.3+-2.1$ & 29 & 39 & 1.1 \\
\hline & & & & & & & $\mathrm{Am}$ & $\mathrm{Aa}, \mathrm{Am}$ & $9.0+-3.0$ & 21 & 32 & 1.0 \\
\hline & & & & & & & Sa & & $13.9+-3.0$ & 50 & 29 & 1.2 \\
\hline
\end{tabular}

